\title{
A KNOWLEDGE FORMALISATION AND AGGREGATION-BASED METHOD FOR THE ASSESSMENT OF DAM PERFORMANCE
}

\author{
Corinne CURT $^{1 *}$, Laurent PEYRAS ${ }^{1}$, Daniel BOISSIER ${ }^{2}$ \\ ${ }^{1}$ Cemagref - Unité Ouvrages Hydrauliques et Hydrologie - 3275 Route de Cézanne - CS 40061 \\ - 13182 Aix-en-Provence Cedex 5 - France \\ ${ }^{2}$ Laboratoire Génie Civil - Polytech'Clermont - Université Blaise Pascal - 24, avenue des \\ Landais - BP 206 - 63174 Aubière cedex - France
}

\begin{abstract}
A computational methodology dedicated to embankment dam performance assessment has been designed and implemented. The model's inputs are the whole set of available information and data: visual observations, monitoring measurements, calculated data and documents related to design and construction processes. Firstly, a formal grid is proposed to structure the inputs. It is composed of six fields: name, definition, scale, references as anchorage points on the scale, and spatial and temporal characteristics. Structured inputs are called indicators. Secondly, an indicator aggregation method is proposed that allows obtaining not only the dam performance but also the assessment of its design and construction practices. The methodology is illustrated mainly with the internal erosion mechanism through the embankment but results concerning other failure modes are provided. An application of the method for monitoring dams through time is given.
\end{abstract}

\section{Introduction}

Guaranteeing that structures are safe and satisfy their functional specifications, and safeguarding heritage are of concern to those involved in design, construction, operation and maintenance. Public and private agencies have always tried to maintain their infrastructure assets, which are subjected to inevitable ageing, in good and serviceable condition at minimum cost (Flintsch \& Chen, 2004). This is very important because the loss of performance of civil structures can lead to:

- various structural or functional deteriorations that may result in accelerated ageing, in additional operational and maintenance costs, in significant loss of water in dams, and in traffic restrictions on bridges;

- failures that can cause dramatic events such as a dam failure or a bridge collapse.

These concerns have produced a rapid increase in the demand for tools and methods able to manage the performance and safety of civil structures since the mid-1960s. Performance is defined as the capability of an infrastructure to perform the functions for which it was designed. However, performance assessment is a difficult task in particular for dams: loss of dam performance is the result of a succession of phenomena (ageing scenarios), stemming from miscellaneous and complex sources that lead to as many miscellaneous and complex consequences, ranging from the deterioration of one or more functions to complete dam failure. Several ageing scenarios lead to loss of performance: for embankment dams, failure can occur by overtopping, sliding shoulders and foundations, and internal erosion inside embankments and foundations.

Several kinds of method are described in the literature to assess dam performance: physical modelling, statistical analysis of historic failures and accidents, systemic methods and methods based on the collection and formalisation of dam deterioration knowledge: (Cyganiewicz et al., 2003) and (Harrald et al., 2004) presented several dam safety risk analysis 
Peyras L., and Boissier D. (2010) A Knowledge formalisation and aggregation-based method for the assessment of dam performance

Computer-Aided Civil and Infrastructure Engineering, 24,3, 171-183.

author-produced version of the final draft post-refeering

the original publication is available at http://www3.interscience.wiley.com/ - DOI: 10.1111/j.1467-8667.2009.00604.x

methodologies; (Adeli \& Balasubramanyam, 1988; Paek \& Adeli, 1990; Adeli \& Hawkins, 1991; Shwe \& Adeli, 1993; Waheed \& Adeli, 2000) developed knowledge-based systems for civil engineering applications. The method we propose is based on this last quoted method. It relies on two main elements. Firstly, various kinds of information and data are available: data from visual inspections, monitoring measurements, calculated data, information from design and construction documents, hydrologic data, etc. Secondly, expert engineers are able to process these information, data and measurements to assess dam performance thanks to their theoretical knowledge and heuristics acquired from dam reviews. Methods based on the elicitation of knowledge exist (Electric Power Research Institute (EPRI), 1986; Franck \& Krauthammer, 1988; Franck \& Krauthammer, 1989; Franck \& Krauthammer, 1989; Andersen \& Torrey, 1995; Bullock \& Foltz, 1995; Andersen et al., 1999; McKay et al., 1999; De Laleu et al., 2000; Hydroquébec, 2005; Peyras et al., 2006; Serre et al., 2006), however, concerning the French dams managed under the authority of the French Ministry of Ecology, there is no formalised approach. Consequently, it appears important to capitalize this knowledge. In this paper a methodology to assess dam performance including both structural safety and ageing effects on materials and associated works is proposed. The method relies on the use of all available information: visual observation, monitoring data, outputs of numerical models and design and construction information. The method and tool associated are dedicated to dam experts. studied:

Several types of dam belonging to two main categories of embankment dam were

- embankment dams with upstream facing: concrete facing, bituminous concrete facing, geomembrane, masonry facing and clay facing;

- embankment dams with internal sealing: homogeneous dams, dams with a central core, dams with core wall.

Knowledge formalised concerned several failure modes: internal erosion through the embankment or through the foundations, internal erosion initiated around or near a conduit, shoulders and foundations sliding, overtopping.

The knowledge elicitation process is presented in Section 2. A model of the approach related to dam performance is proposed in Sections 3 and 4. The method is illustrated mainly with results obtained in the case of dam performance concerning internal erosion through the embankment. An application of the method for monitoring dams through time is presented in Section 5 .

\section{Knowledge elicitation process}

Our study principally aimed at:

- identifying measurement variables corresponding to all the data and information experts use to assess performance. These variables allow the characterization of phenomena liable to lead to performance loss. These different types of data will be detailed in Section 3;

- obtaining their formal description in the form of "indicators" (Section 3);

- aggregating indicators to quantify the various functions performance (drainage, sealing function, etc.), performance related to failure modes (internal erosion, sliding, overtopping) and the assessment of design and construction practices (Section 4).

The control stage that aims at maintaining or replacing dams in standard functioning conditions is not dealt in this paper. 
and aggregation-based method for the assessment of dam performance

Computer-Aided Civil and Infrastructure Engineering, 24,3, 171-183.

author-produced version of the final draft post-refeering

the original publication is available at http://www3.interscience.wiley.com/ - DOI: 10.1111/j.1467-8667.2009.00604.x

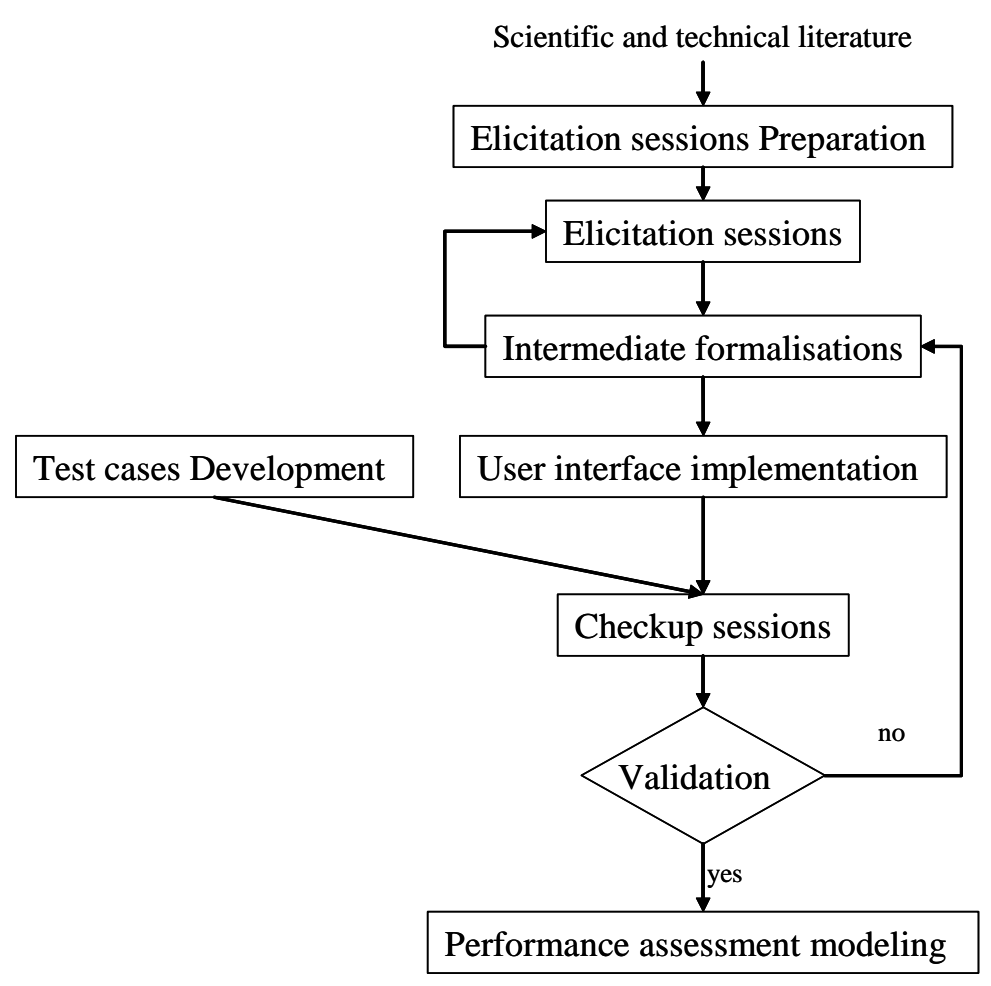

Figure 1: Main stages of the methodology

Figure 1 presents the main stages of our methodology. The core was constituted by elicitation sessions: a panel of five experienced engineers from Cemagref (French agricultural and environmental engineering research institute) was formed and coached by an external observer. These experts had carried out several detailed dam reviews or analysis a year for at least ten years.

The preparation stage was very important (cf. Figure 1): it permitted the external observer in charge of the elicitation to acquaint himself/herself with dam terminology, understand the phenomena that occurs during working life along with ageing scenarios, and preparing elicitation sessions: organization of data collection, documents, questions to be asked, etc. Moreover, this learning was a valuable asset, providing understanding between the observer and the experts. In addition, the preparation phase allows the definition of the structure of the model. Our aim was to formalise dam performance assessment regarding failure modes. Firstly, it was necessary to identify the functions potentially implied in these failure modes. Here they were identified from causal graphs that indicate, as a qualitative approach, the succession of failure modes in dams in ageing scenarios (Peyras et al., 2006). For instance, internal erosion through dam body is due to the loss of performance of three functions: sealing, drainage and embankment erosion protection. The results of these implied functions were compared with those of the literature (Degoutte, 1992; Degoutte \& Royet, 1993; CFGB, 1997; Foster et al., 2000; Degoutte, 2002; Peyras et al., 2006; Royet, 2006). During the elicitation sessions, the functions implied in the failure mode are studied one after the other.

To model performance related to a failure mode, several elicitation sessions followed by intermediate formalisations were necessary.

At the end of the formalisation stage, check-up sessions were performed to valid the inputs and the models proposed for the assessment of performance. 


\section{Identification and description of measurements}

\subsection{Method}

The inputs of the performance assessment model are the whole data set and the information sources the expert engineer uses during dam reviews. We termed them indicators. Four types of indicator related to the origins of the data or information can be distinguished:

- visual indicators from visual inspections performed directly on the site. (Fell et al., 1992) have listed the suggested instrumentation and monitoring systems, in decreasing order according to the number of times they are recommended for different dam heights and hazard ratings (roughly correlated to importance): visual inspection appears at first place. This kind of indicator is of great interest in the performance assessment system;

- instrumental indicators from monitoring devices (piezometry, crack measurements, leakage...) or laboratory or in situ tests (grading, permeability, etc.). Before use, monitoring indicators undergo statistical analysis to take into account external parameters such as headwater level, seasonal effects, pluviometry and time (Bonelli et al., 1998);

- design and construction indicators: geometry (slopes, top width, etc.), material properties (permeability, cohesion, type of geomembrane, etc.), spillway capacity, structural safety updated with reference to possible strengthening (installation of downstream weighting, etc.), reinforcement;

- calculated indicators based on mathematical models with instrumental indicators as input variables: hydraulic gradient, seismic resistance, spillway capacity, sliding index, etc. Intrinsic characteristics of the studied dam (geometry, material properties, etc.) and extrinsic characteristics (headwater level, hydrographs, etc.) are also used.

Once the indicators are identified, a formalisation grid is proposed in order to obtain the information necessary to correctly use the indicators: repeatability and reproducibility must be achieved. All the different types of indicator are described with the same format. We stated that the grid must be made up of a definition possibly completed with operating conditions, a measurement scale and anchorage points on the scale (photographs, schemes, linguistic descriptions), spatial characteristics (sampling, measurement location) and time characteristics (measurement frequency, analysis frequency, etc.). Operating conditions are included in the definition if no specific addition is necessary. By contrast, they are detailed as specific items if additions are important: for instance, crack depth measurements can be performed "at the middle of the length of cracks" or "at the edge of cracks".

Two kinds of measurement scale have been kept:

- one with six marks ranking from "excellent" (0) to "unacceptable" (10), through "good" (1-2), "passable" (3-4), "poor" (5-6), "bad" (7-8-9), used for the instrumental, calculated and visual indicators. The terms were previously adapted from the condition index scale developed by HydroQuébec (eight marks) in a study related to river levees (Serre et al., 2006). Visual indicators are directly expressed in linguistic terms or corresponding numerical scores ("cracking" $=4$ ). Instrumental information is seldom expressed by experts in absolute values but is usually expressed in percentages or trends: it is impossible to provide an absolute value capable of fitting with a set of dams of different heights and features. For instance, a leak of $6 \mathrm{~L} / \mathrm{min}$ stable for 10 years versus a leak of $6 \mathrm{~L} / \mathrm{min}$ increasing by $3 \mathrm{~L} / \mathrm{min}$ over the last 6 months is totally different; 
urt C., Peyras L., and Boissier D. (2010) A Knowledge formalisation and aggregation-based method for the assessment of dam performance,

Computer-Aided Civil and Infrastructure Engineering, 24,3, 171-183.

author-produced version of the final draft post-refeering

the original publication is available at http://www3.interscience.wiley.com/ - DOI: 10.1111/j.1467-8667.2009.00604.x

- the other with four marks ranking from 0 to 10 from "according to rules of thumb" (0), "low deviation", "high deviation" and "non-conformity" (10) is used in the case of design and construction indicators. Deviation is related to rules of thumb.

Instrumental, calculated or design and construction indicators are transferred from a numerical space to the measurement scale (cf. Table 1).

\begin{tabular}{|l|c|c|}
\cline { 2 - 3 } \multicolumn{1}{c|}{} & Numerical value & Value on measurement scale \\
\hline Flow in comparison with & $<5 \%$ & 0 (excellent) \\
\cline { 2 - 3 } drain capacity (considering & $5-20 \%$ & 3 (passable) \\
\cline { 2 - 3 } that flow is constant through & $20-50 \%$ & 5 (poor) \\
\cline { 2 - 3 } time) & $>50 \%$ & 7 (bad) \\
\hline
\end{tabular}

Table 1: Transfer of numerical values on the measurement scale - case of flow measurement

By using a unique scale, a hierarchy is introduced between the indicators from the measurement stage. Indicators can be split up into three groups:

- indicators that provide information about a loss of performance of a function but not about the failure of the function: the possible marks progress from 0 to 7 maximum. This is the case for indicator "cracking of bituminous concrete facing": detection of this deterioration cannot lead to the failure of the sealing function and the maximal possible mark is 6;

- indicators that provide information about the failure of the function: the measurement scale is defined by extreme values i.e. $0,7,8,9$ or 10 . The function is either totally efficient or totally failed. For instance, the indicator "leakage of water through the embankment (absence of entrained particles)", which demonstrates a drainage function failure, belongs to this group. These are qualified as "direct indicators" i.e. indicators specific to a phenomenon or a failure mode and that assign a direct assessment to them;

- indicators that indicate a deterioration or a failure of the function. The measurement scale encompasses a wide range of marks from 0 to 10 . For example, the indicator "Increase of flow" can indicate deterioration or failure of the sealing function: the possible marks range from 0 to 10 .

References are key elements for ensuring the efficiency of the measurement: they are anchorage points on the scale. The aim is to specify the different possible cases so that a measurement performed by several experts, or by the same expert at different times, leads to the same score. To illustrate this, let us take the visual indicator "cracking": in the case of a dam with a concrete facing, scores 1 and 2 correspond to superficial close cracks and scores from 3 to 6 to widened cracks. The choice of score between 1 and 2 or 3, 4, 5 and 6 depends on the number of cracks detected. Figure 2 illustrates the case of a French bituminous concrete faced dam degraded by ultraviolet and thermal actions, leading to important hairline cracking on the first bituminous concrete coat. In this example, a score of 6 would be attributed to the visual indicator. 
Curt C.., Peyras L., and Boissier D. (2010) A Knowledge formalisation and aggregation-based method for the assessment of dam performance,

Computer-Aided Civil and Infrastructure Engineering, 24,3, 171-183.

author-produced version of the final draft post-refeering

the original publication is available at http://www3.interscience.wiley.com/ - DOI: 10.1111/j.1467-8667.2009.00604.x

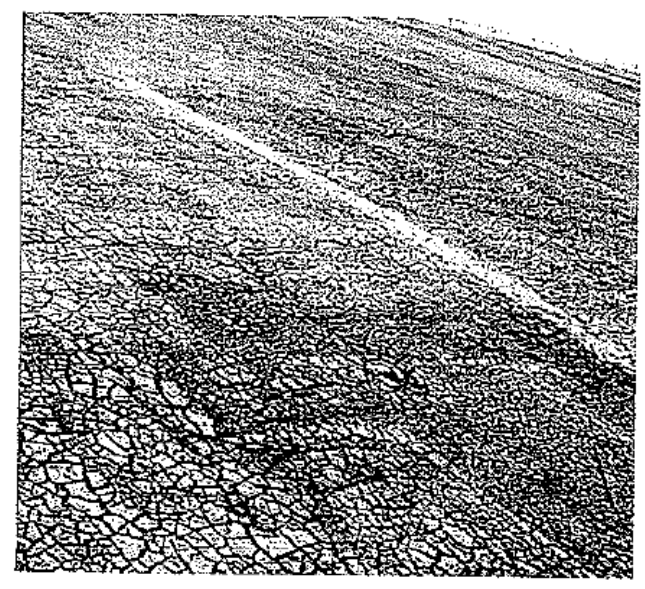

Figure 2: Hairline cracking on bituminous concrete facing dam leading to score 6 given to the watertightness component protection function

The spatial characteristic is of great interest. It is very important to specify where the measurement must be made: crest, foundations, downstream fill, upstream fill and so forth. Indeed, scoring changes as a function of location: the seriousness of a leak depends on the height at which it occurs. Usually, a spatial characteristic is associated with the indicator name: for instance, "leakage on upstream fill". Moreover, the integration of spatial information (surface concerned by the problem and its location) is processed through two strategies:

- elements such as surface concerned by seepage or upstream/downstream location of the measurement device are specified in the grid (cf. Table 2),

- if marks given for one or more indicators vary noticeably along the dam, the assessment is performed considering several profiles.

\begin{tabular}{|c|c|}
\hline Indicator & Scale and references \\
\hline $\begin{array}{l}\text { Clean water seepage } \\
\text { on downstream } \\
\text { embankment }\end{array}$ & $\begin{array}{l}\text { 0: absence of clean water seepage on downstream embankment } \\
\text { 7-10*: presence of clean water seepage on downstream embankment } \\
\text { *: the assessment must take into account: } \\
1-\text { the surface concerned by seepage estimated directly from the } \\
\text { downstream embankment moisture or indirectly from the presence of } \\
\text { hydrophilic vegetation } \\
2-\text { the seepage position related to the embankment height } \\
3 \text { - the seepage flow if possible to measure }\end{array}$ \\
\hline Piezometry & $\begin{array}{l}\text { 0: absence of piezometry above the horizontal drain or downstream the } \\
\text { chimney drain } \\
\mathbf{5 - 1 0 *} \text { : presence of piezometry above the horizontal drain or } \\
\text { downstream the chimney drain } \\
*: \text { the assessment must take into account } \\
1 \text { - piezometer upstream-downstream location (the higher upstream } \\
\text { the piezometry is detected, the higher the assessment) } \\
2 \text { - relative height } \\
3 \text { - change of piezometry }\end{array}$ \\
\hline
\end{tabular}

Table 2: Integration of spatial characteristics in the formal description of indicators 
tion and aggregation-based method for the assessment of dam performance

Computer-Aided Civil and Infrastructure Engineering, 24,3, 171-183.

author-produced version of the final draft post-refeering

the original publication is available at http://www3.interscience.wiley.com/ - DOI: 10.1111/j.1467-8667.2009.00604.x

Three temporal characteristics can be distinguished:

- the frequency of measurement which varies between the various kinds of measurement: temperature and pluviometry are collected daily, piezometry and flow are collected weekly, extensometer measurements are carried out monthly; displacement measurements yearly, etc.;

- the time interval for data processing: monitoring data are processed once a year and trends are analysed by considering a period of a few years;

- the frequency of detailed inspections that does not appear as a specific item in the grid because it is imposed by Regulations: one ten-yearly detailed inspection is performed.

\subsection{Applications}

In this part, firstly, detailed results for the internal erosion through the embankment are provided. Secondly, a synthesis for the other failure modes is supplied.

\subsubsection{Application to the internal erosion through the embankment}

Internal erosion through the embankment constitutes the primary cause of failure and accidents affecting embankment dams (Foster et al., 2000). Internal erosion can only develop if two conditions are met: particles must be torn off and transported (CFGB, 1997). Six phenomena can explain the tearing off of particles: entrainment (or bedload transport), backward erosion, blowout, buoyancy, dissolution and defloculation. Transport can be explained by two mechanisms: piping and suffusion. In the case of piping, particle transport is concentrated in a passage while in the case of suffusion, it is diffused in the porous space between particles. About half of the failures that occurred between 1950 and 1986 were due to piping which is more hazardous and occurs faster than suffusion. If not stopped immediately, it will often cause a failure (Foster et al., 2000). Identified causes of internal erosion are multiple: cracks caused by differential settlement, poorly compacted fill materials, burrowing animals, roots of vegetation...

Table 3 lists the number of formalised indicators for the internal erosion through the embankment. Visual, instrumental, calculated indicators and design and construction practices indicators are distinguished. The sealing function may appear to have a large number of indicators. This can be explained by the presence of several categories of sealing structures, e.g. concrete facing, bituminous concrete facing, geomembrane, masonry facing and clay facing, each being characterised by several indicators.

The grid is applied to the set of identified indicators. Tables 4 to 6 illustrate the results for a visual indicator (sinkholes), a monitoring indicator (decrease of flow) and a design and construction practices indicator. 
Curt C., Peyras L., and Boissier D. (2010) A Knowledge formalisation and aggregation-based method for the assessment of dam performance,

Computer-Aided Civil and Infrastructure Engineering, 24,3, 171-183.

author-produced version of the final draft post-refeering

the original publication is available at http://www3.interscience.wiley.com/ - DOI: 10.1111/j.1467-8667.2009.00604.x

\begin{tabular}{|c|c|c|c|c|}
\hline & $\begin{array}{c}\text { Visual } \\
\text { indicators }\end{array}$ & $\begin{array}{c}\text { Monitoring } \\
\text { indicators }\end{array}$ & $\begin{array}{l}\text { Calculated } \\
\text { indicators }\end{array}$ & $\begin{array}{l}\text { Design and } \\
\text { construction } \\
\text { indicators }\end{array}$ \\
\hline $\begin{array}{l}\text { Internal erosion } \\
\text { through } \\
\text { embankment }\end{array}$ & 20 & 3 & $\mathbf{1}$ & 41 \\
\hline $\begin{array}{l}\text { Sliding of } \\
\text { embankment } \\
\text { and } \\
\text { foundations }\end{array}$ & 24 & 4 & 2 & 40 \\
\hline $\begin{array}{l}\text { Internal erosion } \\
\text { initiated } \\
\text { around or near } \\
\text { a conduit }\end{array}$ & 5 & 3 & $\mathbf{0}$ & 19 \\
\hline Overtopping & 1 & $\mathbf{0}$ & 4 & $\mathbf{0}$ \\
\hline $\begin{array}{l}\text { Internal erosion } \\
\text { through } \\
\text { foundations }\end{array}$ & 21 & 4 & 3 & 49 \\
\hline $\begin{array}{l}\text { Sliding of } \\
\text { foundation }\end{array}$ & 1 & 1 & 1 & 4 \\
\hline
\end{tabular}

Table 3: Number of visual, monitoring or calculated indicators identified and formalised for the different failure modes

\begin{tabular}{|l|l|}
\hline Name & Sinkhole - Subsidence cone \\
\hline Definition & $\begin{array}{l}\text { Local collapse of land surface, usually funnel-shaped, due to spaces and } \\
\text { cavern development underground }\end{array}$ \\
\hline Scale and references & $\begin{array}{l}0: \text { absence of sinkhole or subsidence cone } \\
6: \text { isolated, small (some dm), old (several years) sinkhole OR } \\
\text { presumption of sinkhole (presence of subsidence cone) } \\
7-9: \text { isolated, small (some dm), new (less than 1 year) sinkhole OR } \\
\text { isolated, huge, old (several years) sinkhole } \\
\text { 10: huge and new (less than 1 year) sinkhole }\end{array}$ \\
\hline Location & Crest or upstream shoulder or downstream shoulder \\
\hline Time characteristics & Evaluation carried out once a week \\
\hline
\end{tabular}

Table 4: Description of the visual indicator "Sinkhole - Subsidence cone"

\begin{tabular}{|l|l|}
\hline Name & Decrease of flow \\
\hline Definition & $\begin{array}{l}\text { Flow measurement allows the quantification of infiltrations controlled by } \\
\text { the drainage system }\end{array}$ \\
\hline Scale and references & $0:$ no decrease observed \\
& $\begin{array}{l}1-2: \text { low decrease }(<10 \% / \text { year }) \\
7-8: \text { high and rapid decrease }(>50 \% / \text { year })\end{array}$ \\
& $\begin{array}{l}\text { If: flow suddenly reaches } 0 \mathrm{~L} / \mathrm{s} \\
\text { If the decrease is from } 10 \text { to } 50 \%, \text { no score can be given: the decrease of } \\
\text { flow can be due to a drainage collector collapse, a drain clogging as well as } \\
\text { a spring drying up }\end{array}$ \\
\hline Location & Drain outlet \\
\hline Time characteristic & Flow measurement is carried out once a week \\
& Data processing is carried out once a year \\
\hline
\end{tabular}

Table 5: Description of the monitoring indicator "Decrease of flow" 
tion and aggregation-based method for the assessment of dam performance

Computer-Aided Civil and Infrastructure Engineering, 24,3, 171-183.

author-produced version of the final draft post-refeering

the original publication is available at http://www3.interscience.wiley.com/ - DOI: 10.1111/j.1467-8667.2009.00604.x

\begin{tabular}{|l|l|}
\hline Name & Upstream slope protection filter criteria \\
\hline Definition & $\begin{array}{l}\text { Filter and bedding material along with upstream slope protection makes up } \\
\text { the slope protection system. The filter and bedding material protects the } \\
\text { embankment from hydrodynamic effects of waves and erosion. Its design is } \\
\text { based upon filter criteria. }\end{array}$ \\
\hline Scale and references & $\begin{array}{l}\text { According to rule of thumb: upstream slope protection filter well-designed } \\
\text { Low or High deviation: upstream slope protection filter ill-designed } \\
\text { Non-conformity: absence of upstream slope protection filter }\end{array}$ \\
\hline Location & Upstream slope protection \\
\hline
\end{tabular}

Table 6: Description of the design and construction practices indicator "Filter rules"

\subsubsection{Other failure modes}

Indicators allowing the detection of sliding of embankment or embankment and foundations, internal erosion initiated around or near a conduit, overtopping and internal erosion through foundations were also formalised. Table 3 gives the number of visual, monitoring, calculated and design and construction indicators formalised for each of those failure modes. Some of them are common to two failure modes: internal erosion through embankment and sliding of embankment.

\subsection{Validation}

A validation stage was performed at the end of the elicitation sessions (cf. Figure 1). This stage consists of validation of the whole set of indicator: if experts assess that the indictor is correctly formalised then the validation is successful. If not, experts can express remarks that are integrated during the next elicitation session (alteration of grids).

This stage is performed on the basis of simulations: cases are built from completed dam reports written at the end of detailed dam reviews performed by Cemagref experts. They are composed of a small number of sheets and comprise the following sections: dam description (height, first filling date, reservoir capacity, sealing type, etc.), information from the visual inspection, data from monitoring if any, and photographs. The cases are concerned with different more or less serious problems: leakage on the embankment, sinkhole, and deterioration of the sealing protection system...

The tests were carried out by the five experts using a user interface implemented to automatically assess function performance and performance with respect to the failure modes, and the assessment of design and construction practices. Aggregations are implemented using Visual Basic. The experts were those that participated in the elicitation sessions.

Use of grids during validation sessions allows identifying improvements to be made to the initial description. Around ten indicators were concerned. They were related to all the functions. Alterations concerned the measurement scale (extension of the set of possible marks), the description of marks (insertion of the depth of a crack for the "crack due to creep" indicator that took into account only the location of the crack with respect of the operating level), and so forth. 
vras L.. and Boissier D. (2010) A Knowledqe formalisation and aqureqation-based method for the assessment of dam performance.

Computer-Aided Civil and Infrastructure Engineering, 24,3, 171-183.

author-produced version of the final draft post-refeering

the original publication is available at http://www3.interscience.wiley.com/ - DOI: 10.1111/j.1467-8667.2009.00604.x

\section{Performance assessment modelling}

\subsection{Method}

The inputs of the performance assessment model are visual, instrumental and calculated indicators. The outputs are function performances that concern service limit state and performance of the dam relating to failure modes (cf. Figure 3) that concerns ultimate service state. Mathematical operators and logical equations that link the inputs and the outputs were defined by experts during elicitation sessions.

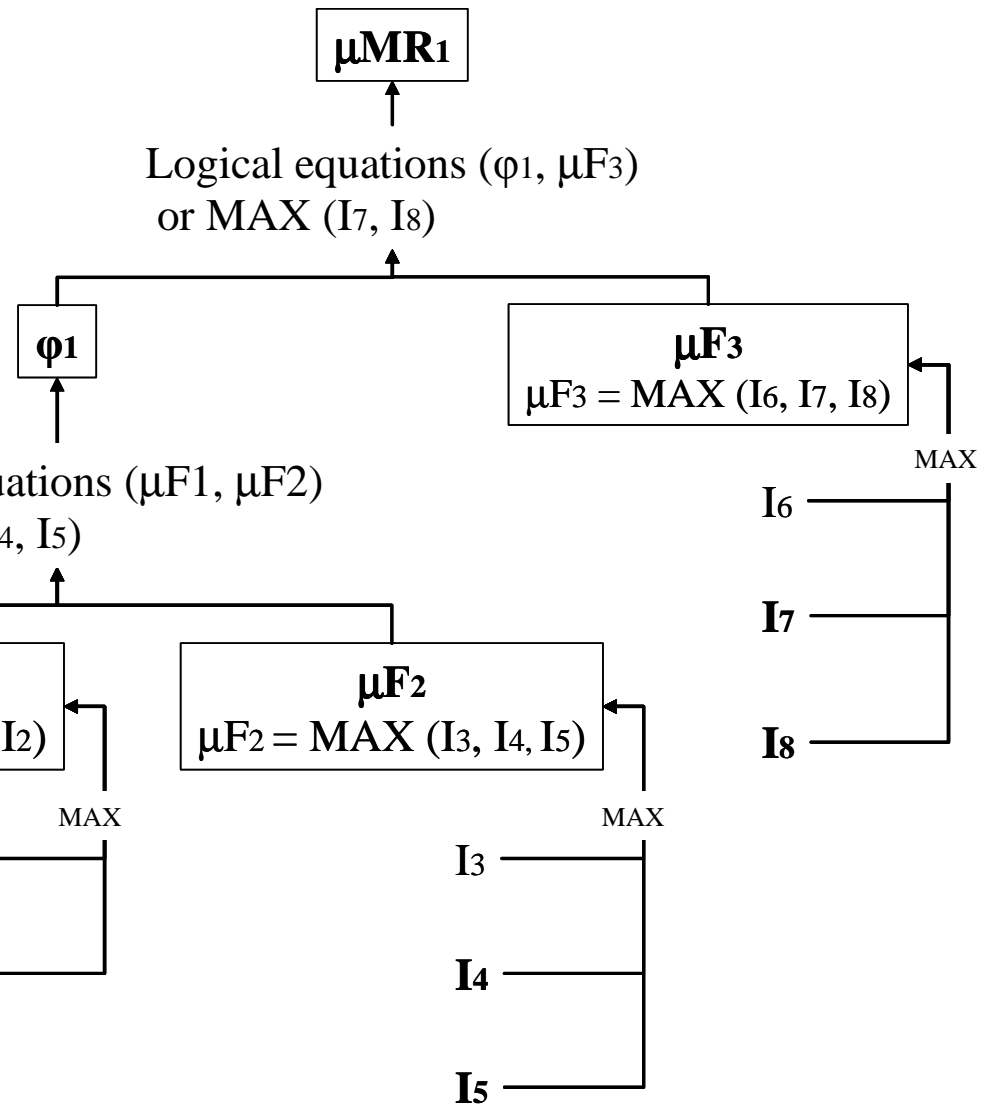

Figure 3: Performance assessment modelling - direct indicators are indicated by bold type $-\mathbf{I j}=$ indicator $\mathbf{j}-\mu \mathrm{Fi}=$ Performance of Function $\mathbf{i}-\mu \mathrm{MR} 1=$ Performance related to the failure mode MR1 - $\varphi 1=$ phenomenon 1

\subsubsection{Function performance}

Function performance $\left(\mu \mathrm{F}_{\mathrm{i}}\right)$ is assessed by calculating the maximum of the values of the $(n-m+1)$ indicators $\left(I_{j}\right.$, implied in the assessment of the function and appraised by experts:

$$
\mu \mathrm{F}_{\mathrm{i}}=\underset{\mathrm{j}=\mathrm{m}}{\mathrm{MAX}}\left[\mathrm{I}_{\mathrm{j}}\right]
$$

For example, the performance of Function $1\left(\mu \mathrm{F}_{1}\right)$ is assessed by MAX $\left(\mathrm{I}_{1}, \mathrm{I}_{2}\right)$ and the performance of Function $2\left(\mu \mathrm{F}_{2}\right)$ is assessed by $\operatorname{MAX}\left(\mathrm{I}_{3}, \mathrm{I}_{4}, \mathrm{I}_{5}\right)$ (cf. Figure 3). The mathematical justification of this operator is linked to the unique scale and hierarchy between indicators. 
tion and aggregation-based method for the assessment of dam performance

Computer-Aided Civil and Infrastructure Engineering, 24,3, 171-183.

author-produced version of the final draft post-refeering

the original publication is available at http://www3.interscience.wiley.com/ - DOI: 10.1111/j.1467-8667.2009.00604.x

\subsubsection{Performance related to a failure mode}

Intermediate calculations are carried out for the assessment of performance related to a failure mode. Firstly, the performances of two functions are combined to assess a phenomenon $\varphi_{\mathrm{p}}$ : for instance, in Figure 3, the performance of Function $1\left(\mu \mathrm{F}_{1}\right)$ and the performance of Function $2\left(\mu \mathrm{F}_{2}\right)$ are combined to assess $\varphi_{1}$. Secondly, the value of the phenomenon is combined with the performance of a third function, here $\varphi_{1}$ and $\left(\mu \mathrm{F}_{3}\right)$. These combinations are performed using:

- maximum operator when direct indicators are concerned (i.e. the indicator value assessed by the engineer is higher than 2). For example, $I_{4}$ and $I_{5}$ are direct indicators of $\varphi_{1}$ (cf. Figure 3). $\varphi_{\mathrm{p}}$ is assessed according to:

$$
\operatorname{IF} I_{D-j}>2 \text { THEN } \varphi_{p}=\underset{j=m}{\operatorname{MAX}\left[I_{D-j}\right]}
$$

where $I_{D-j}$ are the $(n+m+1)$ direct indicators of $\varphi_{p}$

- conversely, logical equations when none of the direct indicators are concerned (i.e. direct indicator values are lower than 2) Logical equations link (i) the performance of two functions involved in a phenomenon (F1 and F2 in Figure 3) or (ii) a function performance with a phenomenon $\left(\varphi_{1}\right.$ and F3 in Figure 3$)$. These logical equations are expressed as "IF-THEN" rules:

$$
\text { IF } \mathrm{I}_{\mathrm{D}-\mathrm{j}} \leq 2 \text { THEN } \varphi_{\mathrm{p}}=\mathrm{f}\left(\mu \mathrm{F}_{\mathrm{a}}, \mu \mathrm{F}_{\mathrm{b}}\right)
$$

where $I_{D-j}$ are $(n+m+1)$ direct indicators of $\varphi_{p}$, f represents a IF-THEN rule defined by experts during elicitation sessions, and $\mu \mathrm{F}_{\mathrm{a}}$ and $\mu \mathrm{F}_{\mathrm{b}}$ are the performance of the two functions involved in the phenomenon $\varphi_{\mathrm{p}}$.

Use of the maximum operator is of great importance as far as computation is concerned: the introduction of a new indicator (a new instrumental measurement for instance) is very easy to carry out. Moreover, logical equations should be not altered after validation, because it is improbable that a new function will be incorporated in the system.

\subsubsection{Assessment of design and construction practices}

A similar but simpler approach is performed for the assessment of design and construction practices $\kappa_{\mathrm{k}}$ (cf. Figure 4 ). The inputs are the design and construction indicators. In this case, only the maximum indicator is used:

$$
\kappa_{\mathrm{k}}=\underset{\mathrm{j}=\mathrm{r}}{\operatorname{MAX}}\left[\stackrel{\mathrm{s}}{\mathrm{I}} \mathrm{I}_{j}\right]
$$

For instance on Figure 4, $\kappa_{1}=\operatorname{Max}(I 1, I 2, I 3)$ and $\kappa_{2}=\operatorname{Max}(I 4, I 5, I 6, I 7)$.

A consequence of these combinations is that the performance and the assessment of design and construction practices are assessed on a scale from 0 to 10 . 
ossier D. (2010) A Knowledge formalisation and aggregation-based method for the assessment of dam performance

Computer-Aided Civil and Infrastructure Engineering, 24,3, 171-183.

author-produced version of the final draft post-refeering

the original publication is available at http://www3.interscience.wiley.com/ - DOI: 10.1111/j.1467-8667.2009.00604.x
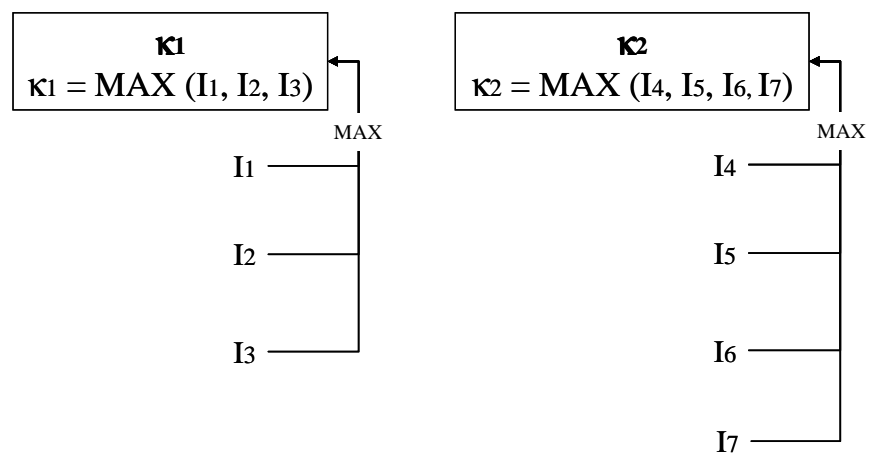

Figure 4: Assessment of design and construction practices $-\mathbf{I j}=\mathbf{i n d i c a t o r} \mathbf{j}-\mathbf{k k}=$ Assessment of Design and Construction practices

\subsection{Application to the internal erosion through the embankment}

Figure 5 gives an instantiation of the model presented in Figure 3. It concerns dams with concrete facing. Three functions were identified: sealing, drainage and erosion defence functions. Fourteen indicators are necessary to assess dam performance regarding the internal erosion mechanism through the embankment; three of them are instrumental (Flow/flow change (increase), Flow change (decrease), Piezometry) the others are visual (Slab cracking, Differential movement...). Four indicators are involved in the performance of the sealing function, six (of which two direct indicators) are in that of the drainage function and four (of which three direct indicators) are in that of the erosion defence function. Some of them are linked: a "Decrease in flow" could correspond to an increase in uplift pressure assessed by "Piezometry".

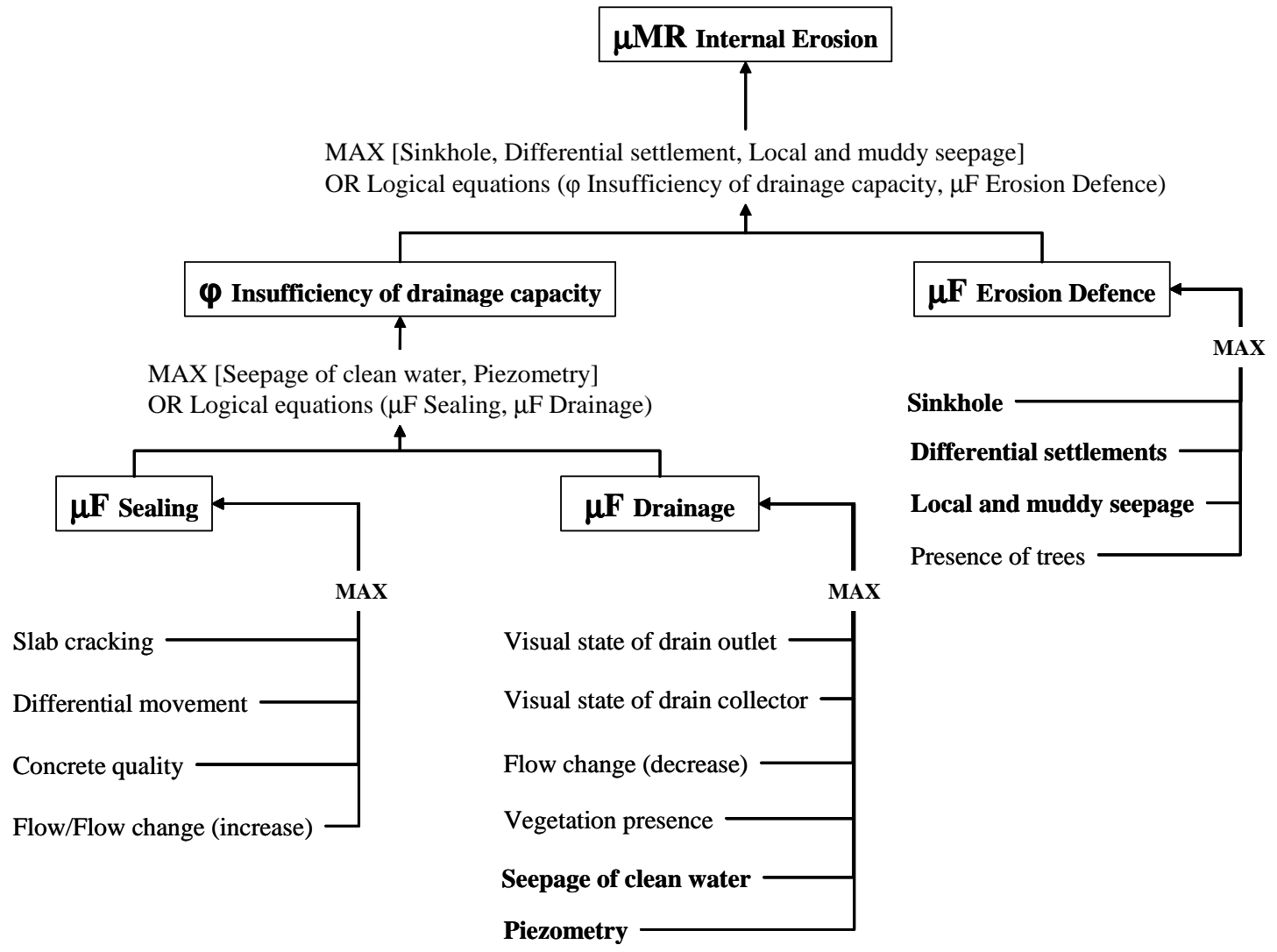

Figure 5: Internal Erosion assessment - Case of dams with concrete facing (direct indicators are indicated by bold type) 
eyras L and Boissier D. (2010) A Knowledge formalisation and aggregation-based method for the assessment of dam performance

Computer-Aided Civil and Infrastructure Engineering, 24,3, 171-183.

author-produced version of the final draft post-refeering

the original publication is available at http://www3.interscience.wiley.com/ - DOI: 10.1111/j.1467-8667.2009.00604.x

\subsubsection{Assessement of Function performance}

Equation (1) allows assessing sealing, drainage and erosion defence function performances:

$\mu \mathrm{F}_{\text {Sealing }}=\operatorname{MAX}[$ Slab craking, Differential Movement, Concrete quality,

Flow / Flow change(decrease)]

$\mu \mathrm{F}_{\text {Drainage }}=$ MAX [Visual state of drain outlet, Visual state of drain collector,

Seepage of clean water, Vegetation presence, Flow change (increase), Piezometry]

$\mu \mathrm{F}_{\text {Erosion defence }}=$ MAX [Sinkhole, Differential settlements,

Local and muddy seepage, Pr esence of trees]

embankment

\subsubsection{Assessement of performance relating to the internal erosion through the}

The first combination aims at assessing the phenomenon "insufficiency of drainage capacity" $\left(\varphi_{1}\right)$ that occurs in the case of a failure of the sealing function and the drainage function: a quantity of water abnormally important enters the dam and cannot be correctly drained by the system of drainage. The phenomenon "insufficiency of drainage capacity" is obtained:

- either by direct indicators of this phenomenon i.e. "clean water seepage" or "piezometry on the downstream embankment" if the values of these indicators are higher than 2. Eq. (2) becomes:

IF "Clean water seepage" $>2$ OR "Piezometry" $>2$

THEN $\varphi_{1}=$ MAX [Clean water seepage, Piezometry $]$

- or by IF-THEN rules (Eq. 3) that combine the performance of sealing and drainage functions if the values of the direct indicators of this phenomenon i.e. "clean water seepage" or "piezometry on the downstream embankment" are lower or equal to 2 :

IF "Clean water seepage" $\leq 2$ AND "Piezometry" $\leq 2$ AND $\mu \mathrm{F}_{\text {Sealing }} \leq 2$

THEN $\varphi_{1}=\mu \mathrm{F}_{\text {Sealing }}$

IF "Clean water seepage" $\leq 2$ AND "Piezometry" $\leq 2$ AND $\mu \mathrm{F}_{\text {Sealing }}>2$

THEN $\varphi_{1}=\mu \mathrm{F}_{\text {Drainage }}$

The same kind of relationships was developed to aggregate $\varphi_{1}$ and the performance of the erosion defence function:

IF "Sinkhole" $>2$ OR "Differential settlements" > 2 OR "Local and muddy seepage" $>2$

THEN $\mu \mathrm{MR}_{\text {Internal Erosion }}=$ MAX [Sinkhole, Differential settlements, Local and Muddy Seepage]

IF "Sinkhole" $\leq 2$ AND "Differential settlements" $\leq 2$ AND "Local and muddy seepage" $\leq 2$

$\operatorname{AND} \varphi_{1} \leq 2$

THEN $\mu \mathrm{MR}_{\text {Internal Erosion }}=\varphi_{1}$

IF "Sinkhole" $\leq 2$ AND "Differential settlements" $\leq 2$ AND "Local and muddy seepage" $\leq 2$

AND $\varphi_{1}>2$

THEN $\mu \mathrm{MR}_{\text {Internal Erosion }}=\mu \mathrm{F}_{\text {Erosion Defence }}$

Table 7 exhibits an example of assessment of function performance and of performance of dam concerning the internal erosion through embankment. Direct indicators are indicated by bold type. Equations (5) to (7) are used to assess the performance of the functions: the 
Peyras L., and Boissier D. (2010) A Knowledge formalisation and aggregation-based method for the assessment of dam performance,

Computer-Aided Civil and Infrastructure Engineering, 24,3, 171-183.

author-produced version of the final draft post-refeering

the original publication is available at http://www3.interscience.wiley.com/ - DOI: 10.1111/j.1467-8667.2009.00604.x

performance of the sealing function is assessed as 6 (poor), the performance of the drainage function is assessed as 7 (bad) and the performance of the erosion defence is assessed as 7 (bad). The next step concerns the assessment of the phenomenon "insufficiency of drainage capacity". As the two direct indicators (Seepage of clean water $=7$; Piezometry $=7$ ) are higher than 2, equation (8) is used for the assessment of the phenomenon "insufficiency of drainage capacity". It is assessed as 7 (insufficiency of drainage capacity $=\operatorname{MAX}[7,7]=7$. The final step consists in the assessment of the performance of dam concerning the internal erosion through embankment. As a direct indicator is higher than 2 (Sinkhole $=7)$, Equation 11 is used for the assessment of the performance of dam concerning the internal erosion through embankment. It is assessed as 7 (performance relating to internal erosion $=\operatorname{MAX}[7,0,0,0]=7$ ). These results show that all the functions implied in this failure mode are deteriorated and need corrective actions to replace this dam in standard functioning conditions.

\begin{tabular}{|c|c|c|c|c|c|c|c|}
\hline \multicolumn{2}{|c|}{ Indicator $\left(\mathbf{I}_{\mathbf{j}}\right)$} & \multicolumn{2}{|c|}{$\begin{array}{l}\text { Performance of } \\
\text { function }\left(\mu F_{i}\right)\end{array}$} & \multicolumn{2}{|c|}{ Phenomenon $\left(\varphi_{k}\right)$} & \multicolumn{2}{|c|}{$\begin{array}{c}\text { Performance } \\
\text { concerning failure } \\
\text { mode } \mu \mathrm{MR}\end{array}$} \\
\hline $\mathbf{I}_{\mathbf{j}}$ & Value & $\mu \mathbf{F}_{\mathbf{i}}$ & Value & $\varphi_{k}$ & Value & $\mu \mathrm{MR}_{\mathrm{l}}$ & Value \\
\hline Slab cracking & 5 & \multirow{4}{*}{$\mu \mathrm{F}_{\text {Sealing }}$} & \multirow[t]{4}{*}{6} & \multirow{10}{*}{$\begin{array}{l}\varphi \\
\text { Insufficiency } \\
\text { of drainage } \\
\text { capacity }\end{array}$} & \multirow[t]{14}{*}{7} & \multirow{14}{*}{$\begin{array}{l}\mu \mathrm{MR} \\
\text { Internal } \\
\text { Erosion }\end{array}$} & \multirow[t]{14}{*}{7} \\
\hline $\begin{array}{l}\text { Differential } \\
\text { movement }\end{array}$ & 0 & & & & & & \\
\hline Concrete quality & 0 & & & & & & \\
\hline $\begin{array}{l}\text { Flow/Flow } \\
\text { change } \\
\text { (increase) }\end{array}$ & 6 & & & & & & \\
\hline $\begin{array}{l}\text { Visual state of } \\
\text { drain outlet }\end{array}$ & 0 & \multirow[t]{6}{*}{$\begin{array}{l}\mu \mathrm{F} \\
\text { Drainage }\end{array}$} & \multirow[t]{6}{*}{7} & & & & \\
\hline $\begin{array}{l}\text { Visual state of } \\
\text { drain collector }\end{array}$ & 0 & & & & & & \\
\hline $\begin{array}{l}\text { Flow change } \\
\text { (decrease) }\end{array}$ & 7 & & & & & & \\
\hline $\begin{array}{l}\text { Vegetation } \\
\text { presence }\end{array}$ & 0 & & & & & & \\
\hline $\begin{array}{l}\text { Seepage of } \\
\text { clean water }\end{array}$ & 7 & & & & & & \\
\hline Piezometry & 7 & & & & & & \\
\hline Sinkhole & 7 & \multirow{4}{*}{$\begin{array}{l}\mu \mathrm{F} \\
\text { Erosion } \\
\text { Defence }\end{array}$} & \multirow[t]{4}{*}{7} & & & & \\
\hline $\begin{array}{l}\text { Differential } \\
\text { settlements }\end{array}$ & 0 & & & & & & \\
\hline $\begin{array}{l}\text { Local and } \\
\text { muddy seepage }\end{array}$ & 0 & & & & & & \\
\hline $\begin{array}{l}\text { Presence of } \\
\text { trees }\end{array}$ & 0 & & & & & & \\
\hline
\end{tabular}

Table 7: Example of performance assessment using the formalization and aggregation-based method - Direct indicators are indicated by bold type

The development of an internal erosion mechanism implies that all the functions concerned (sealing, drainage, embankment erosion defence) have failed. If only one or two of these functions fail, performance concerning internal erosion mechanism is correct at the moment of the assessment.

The model is not chronological, for example the drainage function can fail before the sealing function. 
Peyras L., and Boissier D. (2010) A Knowledge formalisation and aggregation-based method for the assessment of dam performance

Computer-Aided Civil and Infrastructure Engineering, 24,3, 171-183.

author-produced version of the final draft post-refeering

the original publication is available at http://www3.interscience.wiley.com/ - DOI: 10.1111/j.1467-8667.2009.00604.x

The different failure modes (overtopping, sliding shoulders and foundations, and internal erosion inside embankments and foundations, internal erosion initiated around or near a conduit) were described using the methodology and aggregations described above.

\subsection{Validation}

This stage is performed on the basis of simulations using the cases used for the validation of indicators: assessment of the performance related to internal erosion given by the expert and that given by the model are compared using a paired sample comparison. Results show that except for one expert out of five, there is agreement between the score given by the expert and the corresponding score computed by the algorithm.

\section{Application of the method for monitoring dams through time}

The methodology could be used to monitor dams through time. The following presents an experimental example of the monitoring of an embankment dam subjected to internal erosion.

\subsection{Description of the case study}

The Sapins dam in France is a homogeneous dam with a granite arena structure on a granite foundation, $16 \mathrm{~m}$ high, and impounding a $2 \mathrm{hm}^{3}$ lake. It has a vertical drain and a horizontal drain at the foundation interface with the downstream half of the dam. The highest cross sections are instrumented with three pore pressure cells and vertical-drain discharge is recorded.

Reservoir filling began in November 1978. Ten years later in September 1988, a very wet area was noted at the downstream toe. Mid-October 1988, the damp path grew larger, localized slides and muddy seepages could be observed on the upstream shoulder. For safety reasons, it was decided to completely empty the reservoir and improve its structural safety before bringing the dam back into service.

Later, the diagnosis of this major incident which could have led to dam failure showed that the particle size grading of the fill material made it particularly sensitive to internal erosion, leading to the gradual clogging of the vertical drain which did not meet standard filter rules. This fact first led to upstream shoulder saturation; secondly, to overtopping of the drain, which was lower than the normal reservoir level; and thirdly, to saturation of the upstream shoulder. More details on the ageing scenario of the Sapins dam can be found in (Peyras et al., 2006).

\subsection{Results - Performance assessing}

On the basis of various instrumental measurements (piezometry, drain discharge) and visual observations (seepage, local slides, etc.), it was possible, by using the method and tool presented above, to assess and represent the dam's performance at different moments of its history: one expert uses these data to assess the various indicators. Performances concerning the various functions involved in the internal erosion mechanism and the score regarding the internal erosion phenomenon are automatically calculated using the model and the indicators assessed by the expert. Performances concerning the various functions involved in the internal erosion mechanism are represented as radar diagrams while the score regarding the internal erosion phenomenon is represented as a curve on Figure 6. Performances of functions are calculated using Eq. (1) and performance relating to internal erosion is calculated using Eq. (2) and (3). 
as L.. and Boissier D. (2010) A Knowledae formalisation and aqareaation-based method for the assessment of dam performance.

Computer-Aided Civil and Infrastructure Engineering, 24,3, 171-183.

author-produced version of the final draft post-refeering

the original publication is available at http://www3.interscience.wiley.com/ - DOI: 10.1111/j.1467-8667.2009.00604.x
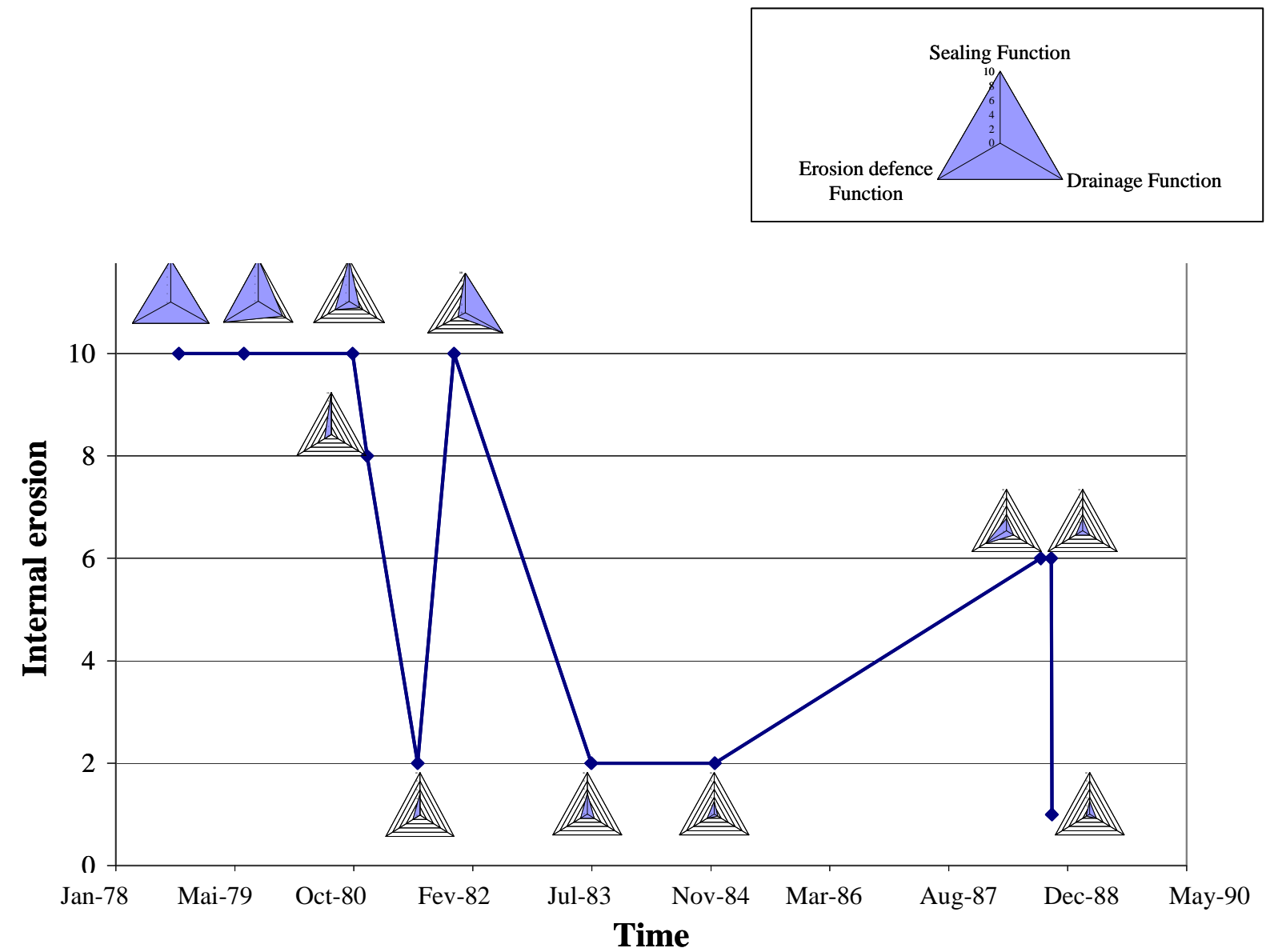

Figure 6: Assessment of the performance through time for the Sapins Dam - The line represents the assessment of the performance related to internal erosion - A radar diagram showing the performance of the sealing function, the drainage function and the erosion defence function is associated to each assessment time

It can be seen that the performance of the various functions and the score concerning internal erosion phenomenon vary through time but shows a progressively worsening trend. The score for the internal erosion phenomenon improved in December 1981: this relative improvement was due to the apparent de-clogging of the drain consecutive to a partial withdrawal of the reservoir. As drainage functioned properly afterwards, the score concerning the internal erosion phenomenon was considered as correct in December 1981. However, Figure 6 shows that this improvement was relative and clogging restarted rapidly: in July 1983, the performance of the drainage function was faulty again. Finally in November 1988, the score regarding the internal erosion phenomenon attained its worst assessment corresponding to the detection of muddy seepage on the upstream shoulder.

As can be seen on this example, the proposed method constitutes a tool for monitoring dam performance through time. The multidimensional but concise representation allows: 
Curt C., Peyras L., and Boissier D. (2010) A Knowledge formalisation and aggregation-based method for the assessment of dam performance,

Computer-Aided Civil and Infrastructure Engineering, 24,3, 171-183.

author-produced version of the final draft post-refeering

the original publication is available at http://www3.interscience.wiley.com/ - DOI: 10.1111/j.1467-8667.2009.00604.x

- rapid identification of damage and problems concerning the performance of the various functions, and the global condition of the dam with respect to failure modes. All these data can be used by experts to propose relevant corrective actions when necessary: for example, concerning the Sapins Dam, downstream rock fill with filters had been installed as an emergency repair, and in 1989, definitive repairs were made in a diaphragm wall. Dams achieving the same score will be not necessary prescribed the same recommendation, because the roots of the problem might be different and because each dam has its own characteristics.

- establishing the damage and problems through time in order to obtain indications on the kinetics of the phenomena. This was possible because the indicator concept allows measurement reproducibility and repeatability.

When using the model, all the data are recorded: indicators function performances and performances relating to failure modes. Then, all these information can be used and recommendations are proposed to correct the performance of functions.

\section{Conclusion}

A computational methodology for embankment dam performance assessment was designed and tested on several simplified real cases and was experimentally applied for the monitoring of an embankment dam subjected to internal erosion: it provided an assessment of function performance and performance related to failure modes. The methodology relies on a panel of five experienced engineers. The inputs of the model are the whole set of information and data available: visual observations, monitoring measurements, calculation data and design and construction information and data. A formal grid was proposed to structure all the inputs, called indicators, using the same format. It ensured the repeatability and reproducibility of the assessment. Moreover, the handing down of knowledge was made easier thanks to formalisation. Dam performance was obtained by indicator aggregation: the performance of the various functions, the performance concerning the failure mode, and the design and construction practices are assessed. The indicators were described for the different failure modes that concern embankment dams: internal erosion through the embankment or through the foundations, internal erosion initiated around or near a conduit, shoulders and foundations sliding, overtopping. Equally, the aggregations were performed for all the failure modes. This method should allow the monitoring of dams through time or the monitoring of a portfolio of dams to prioritize maintenance activities. Real-case studies will be carried out. The method and tool associated are devoted to dam experts but can also be used as training tool by novice engineers only recently involved in dam reviews. Their use needs an actual detailed visit on the dam site. One of the perspectives of this work is to build a new module which will make propositions of corrective actions on the basis of the score obtained by indicators, functions performance and performance related to a failure mode.

\section{Acknowledgments}

The authors would like to thank Gérard Degoutte, Patrice Mériaux, Laurent Peyras, Paul Royet and Rémy Tourment for their participation in the expert panel. They also acknowledge the helpful assistance of Huguette Félix during the construction of the validation cases.

\section{References}

Adeli H. and Balasubramanyam K. V. (1988), A Novel Approach to Expert Systems for Design of Large Structures, AI Magazine, Winter 1988, 54-63.

Adeli H. and Hawkins D. (1991), A hierarchical Expert System for Design of Floors in Highrise Buildings, Computers and Structures, 41, 773-788. 
Peyras L., and Boissier D. (2010) A Knowledge formalisation and aggregation-based method for the assessment of dam performance,

Computer-Aided Civil and Infrastructure Engineering, 24,3, 171-183.

author-produced version of the final draft post-refeering

the original publication is available at http://www3.interscience.wiley.com/ - DOI: 10.1111/j.1467-8667.2009.00604.x

Andersen G. R., Chouinard L. E., Bouvier C. and Back W. E. (1999), Ranking procedure on maintenance tasks for monitoring of embankment dams, Journal of Geotechnical and Geoenvironnemental Engineering, 125, 247-259.

Andersen G. R. and Torrey V. H. (1995), Function-based Condition Index for embankment dams, Journal of Geotechnical Engineering, 121, 579-588.

Bonelli S., Félix H. and Tourment R. (1998), Interprétation des mesures d'auscultation des barrages par régression linéaire multiple 'HST', In 2ème conférence nationale JN-FIAB'98 sur la fiabilité des matériaux et des structures, Marne la Vallée, France.

Bullock R. and Foltz S. D. (1995), REMR Management Systems-Navigation and reservoir structures condition rating procedures for concrete in gravity dams, retaining walls, and spillways, US Army Corps of Engineers.

CFGB (1997), Internal erosion: typology, detection, repair, Comité Français des Grands Barrages, Paris.

Cyganiewicz J., Dise K., Hinchliff D., Mayer D. and Muller B. (2003), Dam Safety Risk Analysis Methodology, U.S. Department of the Interior - Bureau of Reclamation, Version 3.3.1., Technical Service Center, Denver, Colorado.

De Laleu V., Reverchon B., Cault J. B. and Lefranc M. (2000), La politique de maintenance des ouvrages et matériels de production hydroélectrique d'Electricité de France. Une expérience d'analyse de risque simplifiée, appliquée à l'optimisation de la maintenance d'un grand canal, In Vingtième Congrès des grands Barrages, Beijing, Chine.

Degoutte G. (1992), Guide pour le diagnostic rapide des barrages anciens, Cemagref Editions, Paris.

Degoutte G. (2002), Small dams - Guidelines for Design, Construction and Monitoring, Cemagref Editions, Paris.

Degoutte G. and Royet P. (1993), Sécurité des barrages en service, Cemagref Editions, Paris.

Electric Power Research Institute (EPRI) (1986), Inspection and performance evaluation of dams. A guide for managers, engineers, and operators, EPRI Report AP-4714, Project 1745-14.

Fell R., Mac Gregor P. and Stapledon D. (1992), Geotechnical engineering of embankment, Balkema, Rotterdam.

Flintsch G. W. and Chen C. (2004), Soft computing applications in infrastructure management, Journal of Infrastructure Systems, 10, 157-166.

Foster M., Fell R. and Spannagle M. (2000), The statistics of embankment dam failures and accidents, Canadian Geotechnical Journal, 37, 1000-1024.

Franck B. M. and Krauthammer T. (1988), Development of an expert system for preliminary risk assessment of existing concrete dams, Engineering with Computers, 3, 137-148.

Franck B. M. and Krauthammer T. (1989), An expert system for field inspection of concrete dams: Part 1 Engineering knowledge, Engineering with Computers, 5, 23-38.

Franck B. M. and Krauthammer T. (1989), An expert system for field inspection of concrete dams: Part 2 Artificial intelligence issues, Engineering with Computers, 5, 119-131.

Harrald J. R., Renda-Tanali I., Shaw G. L., Rubin C. B. and Yeletasai S. (2004), Review of risk based priorization/decision making methodologies for dams, The George Washington University.

Hydroquébec (2005), Guide d'implantation des indices de condition - Barrages en remblai (document interne), Hydroquébec.

McKay D. T., Rens K. L., Reinmann L. F. and Stecker J. H. (1999), Condition Index assessment for U.S. Army Corps of Engineers civil works, Journal of Infrastructure Systems, 5, 52-60.

Paek Y. and Adeli H. (1990), Structural Design Language for Coupled Knowledge-Based Systems, Advances in Engineering Software and Workstations, 12, 154-166.

Peyras L., Royet P. and Boissier D. (2006), Dam ageing diagnosis and risk analysis: Development of methods to support expert judgement, Canadian Geotechnical Journal, 43, 169186.

Royet P. (2006), La surveillance et l'entretien des petits barrages - guide pratique, Cemagref Editions Paris.

Serre D., Peyras L., Tourment R. and Diab Y. (2006), Evaluation de la performance des digues de protection contre les inondations, Revue Française de Géotechnique, 115, 57-70. 
urt C., Peyras L., and Boissier D. (2010) A Knowledge formalisation and aggregation-based method for the assessment of dam performance, Computer-Aided Civil and Infrastructure Engineering, 24,3, 171-183.

author-produced version of the final draft post-refeering

the original publication is available at http://www3.interscience.wiley.com/ - DOI: 10.1111/j.1467-8667.2009.00604.x

Shwe T. T. and Adeli H. (1993), AI and CAD for Earthquake Damage Evaluation, Engineering Structures, 15, 315-319.

Waheed A. and Adeli H. (2000), A Knowledge-Based System for Evaluation of Superload Permit Applications, Expert Systems with Applications, 18, 51-58. 